\title{
Taking Legal Realism Offshore: The Contributions of Joseph Walter Bingham to American Jurisprudence and to the Reform of Modern Ocean Law
}

\author{
HARRY N. SCHEIBER
}

A conscientious reading of the rich historical literature on the American Legal Realist movement would provide no suggestion that any of the academic writers and other commentators in that movement ever gave the slightest attention

The author is the Stefan A. Riesenfeld Professor of Law and History and serves as Director of the Institute for Legal Research and Co-director of the Law of the Sea Institute at the School of Law, University of California, Berkeley <scheiber@berkeley.edu>. He is an Honorary Fellow and also former president of the American Society for Legal History.

This article is dedicated, in friendship, to my colleague Lawrence $M$. Friedman. An earlier version was presented to a conference in Professor Friedman's honor at the Stanford Law School. I am grateful, for very helpful comments, to Stewart Macaulay and other participants in that conference; and to Robert W. Gordon and Morton Horwitz, the conference organizers, for inviting my participation. David D. Caron of the UC Berkeley School of Law (Boalt Hall) faculty has provided me with many insightful suggestions in the course of my research on ocean law and its history. I also acknowledge with gratitude the librarians who extended themselves greatly to accommodate my requests for materials from the collections at Boalt Hall and at Stanford Law School, Harvard Law School, University of Texas, University of Washington (Special Collections), and the Scripps Institution of Oceanography Archives (UC San Diego). Finally, I am grateful for valuable editorial and substantive suggestions given to me by Editor David Tanenhaus and by two anonymous referees for this Review. 
to international law. ${ }^{1}$ It is entirely understandable that the Realists should be remembered as having been concerned exclusively with the analysis and reform of domestic jurisprudence and legal process; for there was only one exception, in this regard, and this was the Stanford law professor Joseph Walter Bingham. Bingham (1878-1973) is a figure who has been almost entirely neglected by historians of legal thought. ${ }^{2}$ And yet he was one of the earliest American legal commentators to promote an iconoclastic, reformist approach to the common law and American constitutional law. His writings in the $1910 \mathrm{~s}$ and $1920 \mathrm{~s}$, as will be discussed further here, were important early-day contributions to the development of what would become the central canon of Legal Realism. His uniqueness among the Realists rests in the fact that he would go on to play a prominent part in contending for a basic reform in international law during the decades that followed.

In this article, I seek first to lay out the reasons why we should locate Bingham historically as a figure of considerable significance in the history

1. Among the numerous important studies of Legal Realism, one may mention in particular Wilfred E. Rumble, American Legal Realism: Skepticism, Reform, and the Judicial Process (Ithaca: Cornell University Press,1968); William Twining, Karl Llewellyn and the Realist Movement (London: Wiedenfeld and Nicolson, 1973); Edward A. Purcell, Jr., "American Jurisprudence between the Wars," American Historical Review 75 (1969): 424-46, reprinted in American Law and the Constitutional Order, ed. Lawrence M. Friedman and Harry N. Scheiber (expanded edition, Cambridge: Harvard University Press, 1988), 359-74; Laura Kalman, Legal Realism at Yale, 1927-1960 (Chapel Hill: University of North Carolina Press, 1986); Morton Horwitz, The Transformation of American Law, 1870-1960 (New York: Oxford University Press, 1992); John Henry Schlegel, American Legal Realism and Empirical Social Science (Chapel Hill: University of North Carolina Press, 1995); N. E. H. Hull, Roscoe Pound and Karl Llewellyn: Searching for an American Jurisprudence (Chicago: University of Chicago Press, 1997); and Dalia Tsuk Mitchell, Architect of Justice: Felix S. Cohen and the Founding of American Legal Pluralism (Ithaca and London: Cornell University Press, 2007). For excerpts from the writings of the best remembered Legal Realists, with insightful scholarly commentary, see American Legal Realism, ed. William W. Fischer III, Morton J. Horwitz, and Thomas A. Reed (New York: Oxford University Press, 1993).

2. Exceptions with regard to recognizing Bingham's early contributions to Realism are the references to his early writings provided by Rumble some forty years ago, in American Legal Realism, 32, 82-83, 104, 140-41; and brief mentions in Hull, Roscoe Pound and Karl Llewellyn, $75 \mathrm{n} .122,204-5$. Bingham himself left a 110-page informal commentary on his own writings and a partial memoir, List of Writings of Joseph Bingham (1965), on deposit with the Stanford Law School Library. The provenance of this document is documented in George Torzsay-Biber, "A Preliminary Bibliography," Stanford Law Review 17 (1964-65): 1017-18. An informative appreciation of Bingham as a teacher and as a scholar is provided in an unpublished memorial statement by Moffatt Hancock et al., "Memorial Resolution: Joseph Walter Bingham (1878-1973)," http://histsoc.stanford.edu/pdfmem/BinghamJ.pdf. Twining notes that when Llewellyn first entered on law studies as a young man, the published writings of Bingham and Pound were already laying the groundwork for Legal Realism. Twining, Karl Llewellyn and the Realist Movement, 366. 
of American Legal Realism. Not that I want to contend that Bingham had the degree of influence exerted by Roscoe Pound, say, or Karl Llewellyn or Jerome Frank; but I do argue that he clearly deserves a place among the other notables in the pantheon of the movement's founders.

Second, I am concerned to show that Bingham's career was important historically because of his prominent role in carrying both the reformist zeal and the critical intellectual posture of Realism into a prominent area of controversy in international law, starting in the late 1930s. In this area of legal discourse and polemics, he was a central figure in a debate over "offshore jurisdiction" that animated lawyers and diplomats both in America and internationally, beginning at a time of deeply troubled international relations that would soon bring on the Second World War. The debate centered on the sensitive question-one that was of immediate concern to the United States and other naval powers that were then building up for war-of the distance out into ocean waters to which the prerogatives of sovereignty of coastal states could legitimately be exercised offshore.

In this debate of offshore jurisdiction, Bingham stridently challenged the inherited precepts and the prevailing national policies regarding this highly critical aspect of the law of the sea. Legal Realism, as an approach to the law that he had helped launch in the 1910 s, thereby became an intellectual platform from which Bingham now argued for a fundamental departure from customary law and for the adoption of new principles for the law of the sea. Bingham's ideas on the jurisprudence of ocean law and on the need for explicit reforms were influential in their day-just as his writings in the earliest days of the Realist movement had been important for the way they challenged the legacy of classical legal formalism. $\mathrm{He}$ not only functioned as academic gadfly and challenger to classical legal formalism; he also exerted an immediate impact in establishing the terms of policy debate and in influencing actual policy outcomes. ${ }^{3}$ Indeed, in recognition of his influence during the late 1930s upon the formation of American foreign policy, specifically with regard to ocean law doctrines, diplomats would in the 1940 s and 1950 s routinely refer to his developed position on the law of offshore waters and jurisdiction over fisheries-an

3. There were other legal scholars who joined with Bingham to pursue the Realist approach in debates of international law, most prominently Stefan Riesenfeld and William W. Bishop. But in any event they were not of sufficient reputation as of 1938 to be identified as members of the Realist school; their major contributions to international law would come later. On Riesenfeld's collaboration with Bingham, see text at notes 51-57 below. Bingham, it may be noted, is referred to in one respected scholarly study as being in 1950 among "the most eminent authorities in the field of international law." Ernest R. Bartley, The Tidelands Oil Controversy (Austin: University of Texas Press, 1953), 208-9. 
important question then in controversy in international law and foreign relations-as the "Bingham doctrine."

In the field of international law, Bingham's theories on ocean law proved to be not only boldly reformist but also remarkably prescient. This was so because his arguments for reform were in the cause of legitimizing on a "realistic" jurisprudential basis claims of extended offshore jurisdiction by coastal states beyond the limits that then prevailed as customary law (for most nations, including the great naval power Great Britain, three miles; for a few states, as far offshore as twelve miles). Indeed, when the 1982 United Nations Convention on the Law of the Sea (UNCLOS) incorporated as a key provision agreement on authorization for jurisdictional claims out to 200 miles or more, under the rubric "Exclusive Economic Zone," it reflected in a basic sense the rationale that Bingham had advanced in his arguments for ocean-law reform some forty-five years earlier. ${ }^{5}$ This extension of national authority out onto ocean waters far beyond historic limits was a radical proposal at the time Bingham first espoused it, when he

4. The phrase was used frequently, for example, in the internal correspondence and minutes of the British Foreign Office, as will be discussed in a book by the present author, in progress, on the development of modern ocean law, 1937-58.

5 . I use the phrase "in a basic sense" because the essential question in the debate from 1935 to 1982 was whether the old rule in customary ocean law, predominantly a three-mile claim for sovereignty (the territorial sea) with only a few exceptions such as for the hot pursuit of smugglers or protection against pollution out to twelve miles, should yield to a rule that a coastal nation's jurisdiction should be extended out as far as a realistic assessment of practical need for special purposes (e.g., for protection of coastal fisheries resources) would warrant it. The EEZ as provided for by the UN 1982 Convention authorized the 200-mile limit for purposes of regulating economic activity; it did not authorize full sovereignty and in that sense too was fully consistent with Bingham's basic idea that specific types of activity should be covered by offshore jurisdiction to the distance that was warranted by their character and their effect on interests of the coastal state.

An important aspect of the controversy-one that was not explicitly considered by Bingham until after World War II-has to do with the distance to which a contiguous continental shelf may extend, for a particular state, beyond the 200-mile EEZ limit and thus (as the 1982 Convention permits) authorize a claim to economic use of the seabed in the shelf area in question. This potentially dangerous issue is in play, at this writing in 2007, in the Polar area, as Russia (which has planted a flag on the seabed under the North Pole, to highlight its claim of a continental shelf extension to that distance), Denmark, and Canada have all announced claims to shelf distances in the Arctic far beyond 200 miles offshore. See the papers in the special symposium issue on international law relating to the Continental Shelf and offshore jurisdiction of coastal states, in the International Journal of Marine and Coastal Law 21 (Sept. 2006): 263-373; and, for the recent, accelerating developments in the Arctic region, see Daniel Kressey, "Russia at Forefront of Arctic Land Grab," Nature 448 (Aug. 2, 2007): 520-21; "Cold War: Russia Claims Arctic Land," Geotimes, Aug. 2007, at http:// www.geotimes.org/aug07/article.html?id=WebExtra080107.html. Assertive continental shelf claims by the Soviet Union have generated international tensions in the Barents Sea region of the Arctic dating back to the 1960s. 
was reproached by many colleagues in the academy for advocating claims that would escalate controversy among nations that were already on the verge of war. Yet Bingham's ideas have now become integral to the new "constitution for the oceans" that UNCLOS has provided and that serves today as the basic framework for the regime of the global oceans. ${ }^{6}$

Given his innovative role both with regard to Legal Realism and with regard to the reform debates that led to this dramatic re-drawing of the map of ocean jurisdictions, Bingham's ideas and activist record deserve a fresh reconsideration by the historians of American and of international law.

\section{Bingham as a Founder of American Legal Realism}

The obscurity to which Bingham has been largely relegated in the historical studies of Realism is surprising - and certainly is unjustified-if for no other reason than that Bingham's role in scholarly debates of legal theory during 1909-15 was explicitly acknowledged by Karl Llewellyn, Roscoe Pound, and Jerome Frank, among others, as having figured prominently in the articulation of the Realist movement's premises, analytical methodology, and objectives. ${ }^{7}$ Granted, as Rumble wrote years ago, "there is no infallible method to determine who is a legal realist;" 8 and yet any description of the genus would be deficient if it excluded Bingham.

Bingham joined the Stanford faculty in 1907 after earning his law degree at the University of Chicago in 1904, devoting a year to practice and then teaching law at Cornell University during $1905-7 .{ }^{9}$ He wrote his most

6. The term "the oceans," in this legal context, is invoked as including the regimes for use of airspace and economic exploitation of the seabed in the jurisdictional area in question, not only fishing, scientific activity, and maritime and naval operations or other activities on the surface or in the water column. See generally the essays in Davor Vidas and Willy $\emptyset$ streng, eds., Order for the Oceans at the Turn of the Century (The Hague: Kluwer Law International, 1998); and Harry N. Scheiber, ed., The Law of the Sea: The Common Heritage and Emerging Challenges (The Hague: Martinus Nijhoff Publishers, 2000).

7. See text at note 14, below. The objectives of the later Realists varied, of course, with some of them mainly concerned to advance empirical research (and teaching of empirical legal process) and others with more theoretical or policy-reform preoccupations. See Schlegel, American Legal Realism, passim. Bingham's early writing anticipated all these variants, though he made no pretense of pursuing empirical research himself and merely advocated bringing social science and psychology into the analysis of law.

8. Wilfrid E. Rumble, Jr., "Legal Realism, Sociological Jurisprudence, and Mr. Justice Holmes," Journal of the History of Ideas 26 (1965): 547-66 at 547 n.1.

9. Marion R. Kirkwood and William B. Owens, "A Brief History of the Stanford Law School, 1893-1946," http://www.law.stanford.edu/about/history/historysls.pdf - 2003-05-22. See also Hancock et al., "Memorial Resolution." 
influential works in the formative Realist period (perhaps better termed the "pre-Realist era") soon after joining the Stanford law faculty. Bingham's work at Stanford is, incidentally, good reason for recognizing that institution's law faculty as being important in this early history of Realist thought-not like Yale or the others on the standard institutional list for the later period, to be sure, yet important enough for its day. Especially so, given that when Bingham's first important Realist writings were being published Wesley Hohfeld was a colleague of his on the faculty there. Hohfeld was influential in shaping both early Realist jurisprudence and the pragmatic reformist posture of Legal Realism in later years $;{ }^{10}$ unlike Bingham, Hohfeld has received from legal historians the attention he amply merits. Such attention has been without reference, however, to his being a contemporary and a colleague of Bingham's at a time when Hohfeld's own position on consequentialism and pragmatism was taking shape. ${ }^{11}$

10. In most of the historical studies of Legal Realism, the focus of course is upon Yale, Chicago, and Columbia, with Harvard and Pennsylvania as part of the landscape. But Stanford finds mention only insofar as there is passing reference to Wesley Hohfeld's having been on the law faculty there before moving to Yale in 1915. In the last forty years, Lawrence $M$. Friedman's eminent position in Law and Society scholarship, including his work in legal history and in sociology, and the writings of many of his colleagues over the years have given Stanford a highly important place among the major American institutions that carry on the tradition of Realism in legal scholarship.

In her important studies of the subject, N. E. H. Hull uses the term "Progressive-Pragmatic, anti-Formalist movement" to describe the contributions of Pound and others in what I call here the "pre-Realist" period; and she distinguishes it from the later Legal Realism in jurisprudence associated with Llewellyn and the other major figures (see text at note 13, below) who were writing in the late 1920 s and the 1930s. Hull, "Reconstructing the Origins of Realistic Jurisprudence: A Prequel to the Llewellyn-Pound Exchange over Legal Realism," Duke Law Journal 1989 vol.: 1334. See also note 39, below.

11. Twining describes Hohfeld as of 1913, when he submitted his first article for editorial consideration, as a "hitherto unknown professor at Stanford." Twining, Karl Llewellyn, 34. Hohfeld is the subject of much attention in the standard histories and in studies of legal theory. See, e.g., N. E. H. Hull, "Vital Schools of Jurisprudence: Roscoe Pound, Wesley Newcomb Hohfeld, and the Promotion of an Academic Jurisprudential Agenda, 1910 to 1919," Journal of Legal Education 45 (1995): 235-81; and Joseph William Singer, "The Legal Rights Debate in Analytical Jurisprudence from Bentham to Hohfeld," Wisconsin Law Review (1982): 975-1059. Hohfeld was appointed at Stanford in 1905 and remained on the faculty there until taking a sabbatical leave in 1914-15, when he accepted the position at Yale. A Stanford Class of 1913 alumnus later recalled that the influence of Bingham and Hohfeld in the classroom "stimulate[d] deep thought that pierced far below any superficial rust which rested lightly on vague legal terminology." Homer R. Spence, "Joseph Walter Bingham," Stanford Law Review 17 (1964-65): 1009, 1016. Unfortunately little documentation seems to have been discovered that can yield robust information regarding the intellectual or personal relationship of the two men. In a letter to Roscoe Pound, written when Hohfeld was at Stanford and ardently seeking Pound's support in his career, Hohfeld referred rather sarcastically to Bingham's recently published article "What Is Law?" and omitted to men- 
Let us return to the question of how to situate Bingham properly in the intellectual history of Legal Realism. A key indication of his importance as it was seen by the most relevant contemporaries is to be found in the famous lists that Llewellyn and Frank put together in 1931 when preparing to respond to Roscoe Pound's withering attack on the Realists. ${ }^{12}$ In those lists, the giants who are best remembered today all appear: Oliphant, Clark, Cook, Powell, Radin, Douglas, Yntema, Patterson, and the rest of the familiar suspects. ${ }^{13}$ (None of these scholars, of course, had given attention in their writings to problems of international law, except perhaps Max Radin insofar as he was concerned with comparative jurisprudence.) One additional name that Llewellyn and Frank placed at the very head of that list-a name that was included "as of course," Llewellyn stated-was that of Joseph Walter Bingham. ${ }^{14}$

Pound, for his part, concurred in acknowledging Bingham's place in the first ranks of the Realists: for when Llewellyn and Frank challenged him to identify the authors of some specific writings that he deemed exemplary of Realist thought, as portrayed in his critique, Pound came forth with only three specific names-one of which was Bingham's. ${ }^{15}$ Pound linked Bingham with Lorenzen as having been "particularly insistent upon the unreality of supposed rules, principles, and doctrines."16 In refining his own list, Llewellyn placed Bingham in a small sub-group that he categorized as "those who may have taken extreme positions on one point or another."17 Meanwhile, in 1930 Jerome Frank had devoted six pages of his book, Law and the Modern Mind, to a full summary of Bingham's 1912 article entitled "What Is the Law?"- albeit Frank resorted heavily to paraphrasing because

tion Bingham by name. One is left with the impression, taking this letter as a whole, that Hohfeld felt obliged to refer to the article - but that he was not going out of his way to give "marquee recognition" to his colleague; and that he was distancing himself from what he characterized as excessiveness in Bingham's wholesale critique of previous jurisprudential scholarship. Hohfeld to Pound, Feb. 25, 1913, Roscoe Pound Papers, Harvard University Law Library, microfilm, Reel 7. In one of Bingham's later writings (see text at note 38 below), Bingham was explicitly uncomplimentary with regard to Hohfeld's intellectual style. Withal, one sees no sign of cordial colleagueship between the two men in these glimpses from what scant evidence is apparently available.

12. See "Llewellyn's 'Sample' of Realists," in Twining, Karl Llewellyn and the Realist Movement, 76; the successive lists are reproduced in Hull, Roscoe Pound and Karl Llewellyn, 343-46; and the published version in the footnotes of Llewellyn's article, "Some Realism about Realism," Harvard Law Review 44 (1931): 1222, 1227 n.18.

13. See the full account in Hull, Roscoe Pound and Karl Llewellyn, 202-19.

14. Quoted in Twining, Karl Llewellyn, 76; see also Hull, Roscoe Pound and Karl Llewellyn, 204.

15. Hull, Roscoe Pound and Karl Llewellyn, 204.

16. Pound to Llewellyn, March 21, 1931, quoted in ibid., 204.

17. The list sent by Llewellyn to Pound, April 6, 1931, reproduced in ibid., 344. 
of Bingham's "forbidding Austinian style." Frank parenthetically suggested that this difficult prose style was the reason that Bingham had not been given the full recognition that he merited. ${ }^{18}$ Bingham himself reflected ruefully, late in his life, that his early works had been seen by colleagues as "reconditely interesting but practically useless." His viewpoint on legal philosophy, he said, had been too far ahead of his times- "twenty years [before] ... the cult of realists was formed with headquarters at Yale and Columbia." 19

How had Bingham come to be recognized, then, at the time two decades afterward when these giants of Realism, Pound and Llewellyn, were writing their famed exchanges? ${ }^{20}$ Bingham's earliest writings, published in the law journals of Michigan and Columbia, were critical analyses of inherited procedural norms in the common law of property and of torts. ${ }^{21}$ These first efforts, in a retrospective view, firmly establish his credentials as a key figure in the intellectual movement that would later set Legal Realism on its course. ${ }^{22} \mathrm{His}$ main purpose in the early set of articles, Bingham declared, was to establish that law should be viewed "as a field of study analogous to that of any science," and that its subject matter should be subject to objective "scientific investigation" rather than analysis by a methodology that was distorted by reliance on "stereotyped rules and principles." He also concluded that the central concern of judges and scholars seeking to formulate the proper applications of the law must depend on concrete realities of particular cases. ${ }^{23}$

In an overt stab at Langdell and at the concept of immutable rules un-

18. Jerome Frank, Law and the Modern Mind (New York: Brentano's, 1930), 275n. and 274-79. Frank stated that Bingham's work had not come to his attention until after the book had actually been sent to editors for consideration. Ibid., 275n. When Llewellyn sought advice on his list of Realists, in preparation for his response to Pound, he had some correspondence with Bingham-who recommended that Pound himself should be included in that list! Hull, "Reconstructing the Origins," 1317. See also Moffatt Hancock, "Joseph Walter Bingham," Stanford Law Review 17 (1964-65): 1111.

19. Bingham, List of Writings, 7.

20. As Twining has noted, when Llewellyn was still a student in 1919 , papers were already in print by Bingham, along with others by Corbin and by Hohfeld, that "foreshadowed the growth of the Realist movement." Twining, Karl Llewellyn, 366.

21. Joseph Walter Bingham, "Some Suggestions Concerning the Law of Fixtures," Columbia Law Review 7 (1907): 1; "Some Suggestions Concerning 'Legal Cause' at Common Law," Parts 1 and 2, Columbia Law Review 9 (1909): 16, 136; "What Is the Law?" Parts 1 and 2, Michigan Law Review 11 (1912-1913): 1, 109 (1912) with a "Supplementary Note" entitled "The Nature of Legal Rights and Duties," ibid., 12 (1913-1914): 1 (1913); "Some Suggestions Concerning 'Legal Cause' at Common Law," Parts 1 and 2, Columbia Law Review 9 (1909): 16, 136.

22. See quotations in text at notes $15-18$, above.

23. Bingham, "What Is the Law?" 9-11, 13-14. 
derlying a comprehensive jurisprudence, Bingham deplored "the vague current idea that the purpose of scientific investigation is the extraction from their hiding places and the domestication of certain wild beasts of the jungle of ignorance known as principles and rules." 24 The very concept of what one calls a "legal principle," he insisted, must be understood as "a psychological phenomenon" and not as an idea with "an existence independent of the human mind"; and when legal principles or rules "pass[ed] the limits of utility, they should be discarded." 25 Thus did Bingham give new expression to an idea fundamental to Holmes's jurisprudence-an idea carried forward in the contemporaneous writings of Roscoe Pound-to the effect that "the social value of a rule" rather than inherited obeisance to it should be the "test" of its legitimacy. ${ }^{26}$

One of the basic postulates of Legal Realism, in its assault on what Bingham termed "befogging superstitions, mystifying dogmas, and the treadmills of inadequate generalities and sophistical reasoning," 27 was that "rights" or the essential terms of "causes" in torts were formulated in response to specific situations. In these situations, "duties" were inferred from the terms of specific agreements and the factual nature of the objects to which duty and claims referred. This idea was a major theme of Hohfeld's early work, on which Llewellyn would depend heavily, and it was a key element of the attack on the foundation of constitutional formalism and its "rights discourse" based on a concept of natural and universal rights. ${ }^{28}$ Given Hohfeld's association with Bingham at Stanford it is reasonable to see the work of the two on this theme as part of a certainly parallel, though not demonstrably a shared, intellectual enterprise. Indeed, in its broad outlines and the major thrust of its argument, as well as in its more technical aspects, Hohfeld's analysis in 1913 of "fundamental legal conceptions" of duties and rights expressed many of the same ideas that Bingham had been expounding in the years immediately before. ${ }^{29}$

\section{Ibid. 4.}

25. Ibid., 11.

26. Pound, as quoted approvingly in Cardozo, Nature of the Judicial Process (New Haven: Yale University Press, 1921), discussed in Horwitz, Transformation of American Law, 190.

27. Bingham, "What Is the Law?" 119.

28. Horwitz, Transformation, 154 and passim.

29. Hohfeld, "Fundamental Legal Conceptions as Applied in Judicial Reasoning," Yale Law Journal 26 (1917): 711-70. Horwitz points out, however, that Hohfeld essentially "reintroduced a theme highlighted by Holmes forty years earlier-the theme that "duties precede rights, logically and chronologically"-a comment that certainly applies with equal accuracy to the way in which Bingham advanced his arguments on duties and rights. Bingham in his early studies gave explicit credit to Austin, Holmes, and Pound, as well as to J. B. Thayer and others, e.g., in text and footnotes in Bingham, "What Is the Law?" 112-13, 
Also strikingly manifested in Bingham's "pre-Realist" scholarship was a view of the judicial process and of judges' mental processes that foreshadowed some of the later Realists' emphasis upon psychology and law, especially as expressed in Frank's extreme view of the force of subjectivity in judging. ${ }^{30}$ In Bingham's formulation, judges make decisions "not . . . by reference to some mysteriously and anciently evolved system of rules and principles of inherent authority," but rather by "processes of intelligent reasoning" that reflect personal experience and knowledge of the individual judge. Thus "impressions, beliefs, and conclusions concerning the facts of the case, concrete precedents, applicable customs, habits, common ideas, moral blameworthiness, and other logically pertinent considerations are consolidated and welded in generalizations." 31 Bingham rejected the contrary notion, that "law necessarily preexists, that it is something general and authoritative," finding it indefensible in logic or experience; it was merely a manifestation of "the old superstitions." 32 As such it could produce "unwise decisions" and was capable of causing damage to society's community interests.

"There is nothing authoritative in the existence of a rule or a principle," Bingham contended: "Courts produce concrete legal consequences," and the inherited rules should be regarded as valid if-and only if - they passed the pragmatic, essentially consequentialist, test as to what one predicted would be defensible "potential legal consequences."34 Application of or-

120. A Stanford law student recalled as follows the impact of Hohfeld and Bingham upon teaching in his day: "With the zeal of crusaders, these men, each in his own way, started to do some pioneering in the field of attempted clarification of legal concepts and reasoning ... [and] stimulate[d] deep thought that pierced far below any superficial crust which rested lightly on vague legal terminology;" and that this attribute could leave "[an] indelible imprint upon the mind of every law student who is fortunate enough to experience its influence." Homer R. Spence, "Joseph Walter Bingham," Stanford Law Review 17 (1964-65): 1016.

30. The term "pre-Realist" evokes, in this context, the continuing controversy among historians and legal scholars on basic issues of chronology and the proper classification of individuals with regard to Legal Realism. There is a fascination with the questions, Who specifically can be identified as the Legal Realists? And was Realism in a defensible sense actually a "school"? and, in either case, When did the movement begin-and when did it end, if ever? (if indeed it was a "movement" or "school," rather than the term "Legal Realism" being applicable merely as denoting no more than a congeries of loosely interrelated related legal theorists-and legal theories). There is no need here to rehearse the debate of whether Law and Society studies represent a departure in fundamental ways from Legal Realism, or instead (a view to which I adhere) are embedded in Realism's legacy. For an insightful recent commentary, see Stewart Macaulay, "The New Versus the Old Legal Realism: Things Ain't What They Used To Be," Wisconsin Law Review (2005): 365-403.

31. Bingham, "What Is the Law?" 14.

32. Ibid., 17.

33. Ibid., 18.

34. Ibid., 22. 
dinary human intelligence, the analytical equipment and knowledge of the natural and physical sciences—and of psychology — and predictive capacity in order to ascertain the probable social consequences were Bingham's prescription for analysis of the worth of a rule or principle.

This basic idea, which Bingham thus set forth in bold terms as a young scholar in his early years at Stanford, would later become a stock element in the rhetorical and conceptual arsenals of the Legal Realists in the 1930s-the imperative, as stated, for example, by Felix Cohen in 1935, that "creative legal thought will more and more look behind the traditionally accepted principles 'justice' and 'reason' to appraise in ethical terms the social values at stake in any choice between two precedents." 35

Asked to summarize his own credo for a book that appeared in 1941, Bingham sounded the same themes with which he had thrown down the gauntlet three decades earlier. "Systems of philosophy which put life and its purposes in a neat logically coordinated system," he declared, were dedicated to "seek[ing] eternal truth," and as such should be seen as "interesting ... exercises in dialectic," not as a valid way of stating what should be the law. He recognized that they could be influential, no matter how "illusory" in their philosophical foundation; but they could also be "on occasion distinctly pernicious." Historically, Bingham contended, such theoretical systems of law

retarded seriously the development of a science of law founded on a wide and deep study of our very complicated, intensely interesting, and important field of professional efforts, and thereby have contributed to the persistence of bad government and human misfortunes. Indeed generally the highly artificial legal philosophies of Europe have been more concerned with elaboration and maintenance of systematized theory as an end in itself than with intimate knowledge of the facts of life and government and the improvement of society in its governmental phases. ${ }^{37}$

He admitted being resigned to the fact that legal usages were intractablethat "to try, in labored Hohfeldian fashion, to regiment the vocabulary of lawyers and jurists is almost as hopeless as to try to confine the blowing of the wind." ${ }^{38}$ Yet still he remained, as he bluntly described himself, "an American

35. Felix Cohen, "Transcendental Nonsense and the Functional Approach," Columbia Law Review 35 (1935): 809, 833; also in Fischer et al., eds., American Legal Realism, 218.

36. Joseph Walter Bingham, [untitled essay] in My Philosophy of Law: Credos of Sixteen American Scholars (Boston: Boston Law Book Company, 1941), 25.

37. Ibid.

38. Ibid., 11. Although he is easily lumped together with Hohfeld as an Austinian, Bingham in one of his major articles took specific issue with Austin's commitment to traditional usage of the concept of "law." It is "an essential error of Austin's work," Bingham wrote, "that it examines the paraphernalia of the law rather than its substance ... [H]is attempt 
realist" who wrote as "an iconoclast" who was dedicated to engaging in a mission of "advocacy, of opposing attack, of counterattack."39

When the academic firestorms of legal debate first broke out in the late 1920s and early 1930s, he was not an active player among the Legal Realists-although, as we have seen, his earlier contributions to Realist thought became well recognized at that time. This is not to say that he was inactive, by any means. He had turned his attention to international law, and he participated in this arena with all the energy and reformist zealousness that he had brought to his earlier Realist studies of domestic law and legal philosophy.

\section{Bingham's Campaign for Ocean Law Reform}

It would have seemed unlikely when Bingham first established himself as a scholar at Stanford that twenty years later he would become a major figure in the American academy in the field of international law. Bingham served during World War I in the War Trade Board and is said to have become interested there in international law, a field not then offered in the Stanford teaching curriculum but in which he began to conduct research. ${ }^{40} \mathrm{He}$ took a major part in the Harvard international law codification project, serving as the reporter for the project's study of the law of piracy, published in $1932 .{ }^{41}$ Meanwhile he had also developed a specialty in water law at Stanford; and in 1934 he published an article contending for reform of California's riparian rights doctrine that was later influential with the state's high court. ${ }^{42} \mathrm{He}$

to harmonize and unify led him into artificialities ... [His] emphasis was so strongly laid on definition that the work does not approach a scientific exposition of the field of law and its elements." Bingham, "What Is the Law?" 3 n. 4.

39. Bingham, "My Philosophy of Law," 7. Emphasis added.

40. Kirkwood and Owens, "Brief History of the Stanford Law School," cited above, in note 9 .

41. [Joseph Walter Bingham, Reporter], Draft Convention on Piracy (Harvard University Law School, Research in International Law), in American Journal of International Law 26, Supplement (1932): 739-49. This report would later have an important influence on the project of the UN International Law Commission when it worked on codification of the law of the sea in the 1950s. Barry Hart Dubnev, The Law of International Sea Piracy (The Hague: Martinus Nijhoff, 1980), 37-93. A remarkably prescient aspect of the report was the attention it gave to the possibility of acts of terrorism or piracy "in or from the air," in light of the advances in aviation. Whether or not this was a contribution we can specifically identify with Bingham, the willingness to go beyond the traditional wisdom and historical definitions of piracy (confined to acts at sea) was certainly consistent with his intellectual style. See ibid., 52-64.

42. Bingham, "Some Suggestions Concerning the California Law of Riparian Rights," California Law Review 22 (1934): 251-76, proposing a procedural change that the California Supreme Court adopted in Peabody v. City of Vallejo, 2 Cal. 2nd, 351, 40 Pac. R. 2nd 486 (1935). 
took time as well to do research for the major article of 1936 that set out a pragmatic, quintessentially Realist, critique of the law of property rights in divorce cases involving conflicts of law-presenting an alternative approach that in fact was later adopted by the U.S. Supreme Court in a decision that overturned long-established doctrine. ${ }^{43}$ In 1941, he would also publish a revision of an established case book on wills and inheritance. ${ }^{44}$

What came to interest Bingham most, however, were the central issues in international law relating to the rights and duties of states in coastal and high seas areas of the oceans: issues of sovereignty, legitimacy of nationstate claims, and what he saw as the imperatives of technological innovation and scientific management in the rapidly changing arena of ocean resource use. These imperatives, especially with regard to the exploitation of ocean fisheries by ever-larger fleets of ever more powerful vessels and gear, Bingham asserted, required an abandonment of customary norms and demanded a radical revision in the jurisprudential principles of ocean law. In the new arena of debate that emerged in the late thirties, Bingham engaged these questions with the same level of energy, iconoclasm, and zest for polemical combat as he had shown in his earliest academic years. His objective now was to advance a reform campaign that would transform basic principles of coastal state rights and ocean law. In the course of his new involvements, it may be said Bingham carried "offshore" the cause of Legal Realism

Just as Bingham had attacked classical formalism in law during his earlier years, the inherited formalist precepts of international law became his new target when he undertook his reformist campaign in the realm of ocean law. The specific issue on which he wrote was the law of territorial waters-the rules that prescribed the geographic distance and functional scope of coastal states' jurisdiction over ocean areas and marine resources off their shorelines; and in particular, he sought a re-conceptualization of the rights of coastal states to regulate offshore fishing that was conducted by vessels operating under foreign flags. At the time, in the dominant Anglo-American tradition in international law, the "three-mile" rule of territorial waters was held virtually sacred..$^{45}$ This concept, which had come down in the tradition of Grotius since

43. Bingham, "The American Law Institute vs. The Supreme Court-In the Matter of Haddock v. Haddock," Cornell Law Quarterly 21 (1936): 393. The Supreme Court decision on "divisible divorce" that adopted his position was in the case of Vanderbilt $v$. Vanderbilt, 354 U.S. 416 (1957), as is discussed in Hancock, "Joseph Walter Bingham," 101 1. Bingham returned to the theme of the Haddock Case in his article, "Song of Sixpence: Some Comments on Williams v. North Carolina," Cornell Law Quarterly 29 (1943): 1-27.

44. Joseph Walter Bingham, Cases and Materials on Wills, Descent and Administration, by George P. Costigan, 3rd ed. (St. Paul: West Publishing Co., 1941). Bingham years earlier had published as sole author and editor, Estates of Decedents (Chicago: LaSalle Extension University, 1913).

45. This can be said with reference to the standard Anglo-American legal literature up to the mid-1930s, though historically the three-mile limit had been made subject to exceptions 
the seventeenth century, involved, among other things, the rule that beyond a fixed limit off the shores of coastal states the ocean's fishery resources comprised a commons that could not legitimately be claimed or controlled by any individual state. Although some coastal nations maintained a claim to ownership of the seabed or jurisdiction over fishing out to nine or even twelve miles beyond the shoreline, the United States and the United Kingdom had long adhered to the three-mile rule and contended for its universal application, as did other interested marine nations that accepted the rule as being part of customary law. ${ }^{46}$ With regard to ocean fisheries, the three-mile rule meant that beyond that boundary line out to sea, the ships of any and all nations were free to engage in their harvest without controls by any nation other than their own flag nation. In practice, few nations exerted any kind of restrictions over the high-seas fishing activities of their nationals, either as to target fishery species, the volume or method of catch, or, en fin, any consideration of sustainability and conservation. Indeed, the ocean fisheries had long been regarded as inexhaustible, giving additional legitimacy to the three-mile rule and its variants. ${ }^{47}$

By the 1930s, however, it had become evident that marine fisheries could be depleted by overfishing in this traditional regime that was called-with significant rhetorical effect--the regime of "freedom of the seas." Steamdriven ships of ever larger scale and capability for distant and prolonged voyages, refrigeration of catches at sea, and diesel power were producing a dramatic rise in the volume of ocean fisheries harvest recorded by the world's fishing fleets. Bilateral and multilateral international agreements were negotiated to deal with the overfishing threat, but these agreements

by even the United States and the United Kingdom; and it was not accepted universally, since many coastal states claimed up to nine or in some cases twelve miles for purposes of regulating fisheries or other activities, and (as noted in the text, below) a few claimed full sovereignty (not just special jurisdiction for limited purposes) over territorial seas of more than six miles. See the standard historical and legal analysis by Stefan A. Riesenfeld, Protection of Coastal Fisheries under International Law (New York: Carnegie Endowment for International Peace, 1942); and also William E. Masterson, Jurisdiction in Marginal Seas, with Special Reference to Smuggling (New York: Macmillan, 1929); Sayre A. Swarztrauber, The Three-Mile Limit of Territorial Seas (Annapolis: The Naval Institute Press, 1972); and the brief discussion in Douglas M. Johnston, The International Law of Fisheries: A Framework for Policy.Oriented Inquiries (New Haven: Yale University Press, 1965), 171-76.

46. For the classic argument that the three-mile rule was "established international law," see Philip Jessup, The Law of Territorial Waters and Maritime Jurisdiction (New York: G. A. Jennings Co., 1927), chap. 1, passim. An authoritative work on ocean law, unique in the literature for its integration of legal development and related changes in technology, science, resource exploration, and public policies, is Lawrence Juda, International Law and Ocean Use Management: The Evolution of Ocean Commerce (London: Routledge, 1996).

47. Harry N. Scheiber, "Ocean Governance and the Marine Fisheries Crisis: Two Decades of Innovation-and Frustration," Virginia Environmental Law Journal 20 (2001): 119-23. 
applied to very few of the great stocks of commercial fish in the world's oceans. Therefore, by the mid-1930s the rising scale of marine fishing harvests had become alarming to most fishery scientists and to government officials in the major maritime nations globally. ${ }^{48}$

Among the law writers in the field of international law, the dominant (though not universally accepted) view was that "freedom of the seas" and the narrow territorial sea, as traditionally defined with regard to freedom to fishing, navigation, or waste disposal, was a matter of "rule of law" established through customary practice, i.e., widespread acceptance by maritime states. And as such, the established rule would serve the interests of stability and peace, it was contended, because a clear rule demarcating the norms for behavior on the high seas was a deterrent to dangerous clashes of interest that could provoke the uses of force between maritime nations. The legal traditionalists did not oppose orderly processes for reform of the strict three-mile rule: They contended instead that any revision of such a basic rule should be pursued only by treaties as part of a consensual process that would reshape the established universal customary law in international affairs. Self-interested, unilateral action to extend jurisdiction seaward was seen as menacing to the peace. ${ }^{49}$

Bingham would launch a sustained campaign, in the Realist vein, against these traditional views in international law. He would argue that customary international law had developed historically precisely as the common law had developed-as an ongoing process of change in which new technological, economic, and social imperatives had led to the adaptations in

48. David Cushing, Fisheries Resources of the Sea and Their Management (Oxford: Oxford University Press, 1975); F. S. Russell, The Overfishing Problem (Cambridge: The University Press, 1942). See also Harry N. Scheiber and Christopher J. Carr, "From Extended Jurisdiction to Privatization: International Law, Biology, and Economics in the Marine Fisheries Debates, 1937-1976," Berkeley Journal of International Law 14 (1998): 10-54.

49. E.g., Philip C. Jessup, "The Pacific Coast Fisheries," American Journal of International Law 33 (1939): 134. Riesenfeld calculated that in the literature published during 1800-1899 of 113 acknowledged legal commentators on ocean law, 94 accepted the three mile (or "cannon-shot") rule as authoritative; but from 1900 to ca. 1939, of 114 commentators, only 61 regarded the rule as definitive as a matter of customary law: Coastal Fisheries, 279. Taking account of the nationality of each writer would, of course, be a useful indicator of bias in the aggregate numbers. Nonetheless, there is no question that Bingham was on firm scholarly ground in saying that the three-mile rule had been challenged in important ways, both in state practice and in learned commentary. Indeed, one of the central objectives of the Harvard project on the law of piracy, for which Bingham served as rapporteur, was to advance the concept of an "extraordinary basis of jurisdiction" in offshore waters for actions enforcing against pirates (quoted in Dubner, Law of International Sea Piracy, 48). As noted above (note 41), the Harvard project's report was remarkable in going beyond the prevailing intellectual boundaries of ocean law and in foreseeing that piracy might one day, "with rapid advance in the arts of flying ...," take the form of action by "bands of malefactors" who would "engage in depredations in or from the air." Quoted in ibid., 68. 
law and the acceptance of new doctrines-and that ocean law as it stood in the 1930s required the same kind of radical reforms as had successfully challenged the classical legalism of American domestic law.

Bingham's views came to prominence in a global debate of ocean fisheries questions as the immediate result of a diplomatic confrontation that involved the United States, Canada, and Japan in the late 1930s. For the United States, the appearance in 1937 and 1938 of Japanese-flag factory-ship fleets in the Bering Sea-an ocean area rich in salmon that long worked had been the exclusive domain of American fishing interests-made palpable the threat that the modernization and expansion of industrial fishing posed to both the fish resource itself and to the interests of coastal states. In this instance, the interest in question was a domestic salmon-fishing industry that been sustained by operation of governmental fish hatcheries, the fishing fleet itself having been closely regulated by the U.S. government in an effort to maintain the salmon stocks on a sustainable basis. In addition, a pending Canadian-U.S. treaty regulating the two nations' Pacific salmon industries would be rendered ineffective if a third party (let alone one employing largescale factory vessels) should enter into the waters just outside the existing American and Canadian three-mile limits of jurisdiction. ${ }^{50}$

Inspired by the threat to American fishing interests represented by the Japanese government's licensing of factory vessels to operate in Bristol Bay, the Institute of Pacific Relations-an organization in which the Washington and Alaska salmon industries had considerable influence-commissioned in 1936 a legal research project on the subject of the three-mile rule. The expectation was that such a study would suggest a re-evaluation of the rule's appropriateness in light of the changes in marine fishing technology and would explore the possibilities for reform of international law. It was probably at the suggestion of Ray Lyman Wilbur, president of Stanford University and then a director of the Institute, that Professor Bingham was given the contract for this study. In any event, Bingham accepted the assignment; and he had the good fortune to engage as research assistant for it a young German-American immigrant scholar, Stefan A. Riesenfeld, who had studied law in Europe and was then completing graduate studies at the University of California's School of Law in nearby Berkeley. ${ }^{51}$

For Bingham, the research assignment was an opportunity to examine

50. In addition, the United States and Canada had put into effect a treaty by which they applied a joint regime of regulation to conserve and manage the halibut resources of the West Coast; they were still in process of working out the bilateral agreement for regulation of the salmon fisheries of the two nations. Also, the United States had invested millions in salmon hatcheries operations on salmon streams in Alaska. See, inter alia, Larry Leonard, The International Regulation of Fisheries (Washington, D.C.: Carnegie Endowment for International Peace, 1944).

51. Interviews with the late Stefan A. Riesenfeld by the author, 1988, and later conversations on the subject with Prof. Riesenfeld. 
through the lens of Legal Realism an intriguing and controversial issue in law and policy. For the U.S. Department of State (which may possibly have encouraged the IPR to undertake the project), it offered hope that scholarly support might be forthcoming to support the position it had taken in diplomatic protests to Japan against the recent incursions into the Bristol Bay. ${ }^{52}$ For in the 1937-38 confrontation, the State Department had indicated to Japan that the need to protect existing American fishing interests in the Bering Sea could justify an extraordinary departure from the rule limiting U.S. jurisdiction to only three miles offshore..$^{53}$ The Bingham study was also seen as a possible source of academic support for President Franklin D. Roosevelt's personal view, which he had expressed privately to the State Department lawyers: It would be desirable, Roosevelt stated, for the United States to extend its offshore jurisdiction by presidential proclamation and thereby to "create a kind of marine refuge," well beyond three miles out to sea on Bristol Bay, so as to protect the American fishing interests; there was no doubt that the Japanese would protest against such a violation of the traditional "freedom of the seas." 54 As for Riesenfeld, the project developed into an opportunity for him to pursue the research question well beyond immediate purposes; and ultimately, with Bingham's approval and support, Riesenfeld produced his great historical and jurisprudential treatise, Protection of Coastal Fisheries under International Law. The book was completed in 1939, but for reasons essentially political it was not published until $1942 .{ }^{55}$

52. Riesenfeld stated that insiders at the time believed that the State Department had encouraged the commission by the IPR. Ibid. In the research for the present study, no documentation was found either in the IPR records or State Department archives to confirm that this was so. The State Department records leave no doubt, however, that lawyers in the department were keenly interested in how the study would come out; and they referred to it often in their memoranda after its publication. Bingham wrote years later that he was first drawn into the project by his friend the attorney Edward W. Allen of Seattle, who was a board member of IPR. Allen had been a fraternity brother of his at the University of Chicago, and in the 1930s he was prominent in international law circles and served as counsel to the salmon fishing and cannery industries of Alaska and Seattle. By the late thirties Allen was campaigning vigorously for a change of U.S. policy that would keep Japanese ships out of the Bristol Bay waters that were so important for American and Canadian salmon. Bingham, List of Writings, 43-45. On Allen's role in this regard, see text at notes 74-76 below.

53. Harry N. Scheiber, "Origins of the Abstention Doctrine in Ocean Law: Japanese-U.S. Relations and the Pacific Fisheries, 1937-1958," Ecology Law Quarterly 16 (1989): 29-32. Parts of the discussion in the immediately following paragraphs of this article draw upon material in this article and several other, later writings of mine on the history of modern fisheries oceanography and international law.

54. Franklin D. Roosevelt to R. W. Moore (Legal Counsel, Dept. of State), Nov. 21, 1937, in Foreign Relations of the United States, 1937, vol. 4 (Washington, D.C.: Government Printing Office, 1954), 768-69.

55. International law scholars in the traditionalist camp who served on the IPR board or as advisers were aghast at what they regarded as Riesenfeld's attack on "rule of law," and IPR asked Riesenfeld to accept publication with a preface by Philip Jessup or another 
While Riesenfeld continued working on what became his magisterial study, Bingham seized on their joint research findings to produce quickly a pamphlet-length study, Report on the International Law of Pacific Coastal Fisheries. It was published in 1938, with a subsidy from the Alaska salmon packers trade association, after the original sponsors at IPR backed off out of concern about its polemical character. ${ }^{56}$ Bingham made no pretense as to the polemical purpose of his Report as legal scholarship; he left the larger scholarly objectives to Riesenfeld. In a private letter, Bingham said that he was convinced that the abandonment of the three-mile rule by the United States was "inevitable"; hence he saw no point in making his report "discreet [or] purely technical," and in any case he was "opposed to pussy-footing." 57 "It is a brief," he declared in the report itself, "and as a brief which seeks to influence others and to convert a Phalanx of American legal opinion saturated with traditional doctrine, it has been modeled for emphasis." 58 When his colleagues urged him to tone it down, out of concern it would antagonize the Japanese government and would harm his standing in the law school world, he declined to accept such an idea ${ }^{59} \mathrm{He}$ wrote out of a belief, Bingham asserted, that it was "of the utmost importance to the future peace and security of the United States" to see American interests on the Pacific Coast protected against the Japanese threat and other contingencies-and that such protection, so far as the fisheries were concerned, should be "extend[ed] as far from our Coast as efficiency demands." 60

The law of territorial waters, he continued, "is a remarkably fertile field for the development of adequate principles of law pertaining to natural resources which may be wasted by unrestrained exploitation." To fashion such principles required abandonment of the three-mile rule, which he dismissively referred to as "the Anglo-American doctrine"-a rule adopted

senior scholar. He refused. When the United States entered the war in December 1941, the Riesenfeld position, regarded as aggressive vis-à-vis Japan, no longer seemed objectionable; and the Carnegie Endowment stepped in and agreed to publish Riesenfeld's study as a major book publication. Information from the manuscript correspondence files in the IPR archived records, Special Collections, University of Washington Library, Seattle.

56. Report on the International Law of Pacific Coastal Fisheries (Palo Alto: Stanford University Press, 1938). The story of how IPR withdrew support and the intervention and subsidization by the packers is recalled by Bingham in Bingham, List of Writings, 49 .

57. Bingham to William Lockwood, June 7, 1939, copy in Allen Papers, University of Washington Library.

58. Bingham, Report on the International Law of Coastal Fisheries, preface, v-vi. Italics added.

59. Bingham, List of Writings, 49.

60. Report, vi. His account is confirmed by correspondence in the IPR Papers, University of Washington Library. See note 55, above. 
as their own policy and championed in global affairs by the United Kingdom and the United States out of naked self-interest, even though it was contributing to a continuing situation of "chaotic problems of legal control of sea fisheries." ${ }^{61}$ For the claims of sacredness for the inherited canon of "freedom of the sea," Bingham reserved his most scornful rhetoric, deploring "the comfortable conviction" that because a doctrine had been of long standing it should be "frozen" and perpetuated without regard to current realities and interests. To think that such a rule had "reached maturity" in any event, in a linear process that recognized rightful principles, was in any case "an academic delusion." 62

At the May 1940 meeting of the American Society for International Law (ASIL), Bingham's position on the three-mile rule was the subject of a special panel session in which his principal critic was Professor Philip Jessup of Columbia Law School. There was no mystery as to how the debate would go: Jessup had just recently published his view that to extend jurisdiction unilaterally in the Bristol Bay area would aggravate the existing diplomatic confrontation of America with Japan, increasing the danger of armed conflict ${ }^{63}$ For his part, Bingham was already on record with regard to how the East Coast establishment in international law (no one in that category more prominent than Jessup) was so "engrossed ... with European and Atlantic events and problems [that] they often even today fail to realize the great importance of the Pacific Coast affairs for the future of the country." For this reason, their failure, as he saw it, to respond to Japanese fishing in the Bering Sea resulted from their being locked in to the traditional position that enshrined the three-mile rule. ${ }^{64}$ And so the lines had already been drawn when the academic dignitaries gathered for the jousting at the ASIL panel.

Bingham opened the panel session by asserting that the inherited structure of international law had already been "shattered" by the "tides of change" of the twentieth century; and so America's reliance on the "traditional tenets" of law-let alone reliance on the hope, to which Jessup clearly held fast, that the existing structure of international law offered the basis for peace among nations-must obviously be given up. ${ }^{65}$ Once again deploying the now-familiar Realist style and rhetoric, Bingham declaimed against the belief (held by "complacent conservatives-a vanished race today") in the benign nature of allegedly "definitive principles of justice

61. Bingham, Report, 9-10.

62. Ibid., 23.

63. Jessup, "The Pacific Fisheries," 134-38. The ASIL panel is discussed briefly, in broad historical context, in Juda, International Law, 112-13.

64. Bingham, Report, 49.

65. American Society for International Law, Proceedings, 1940, 54-55. 
established in tradition, existing independently of particular contending forces, economic, political and social ... ." the convergence of Realpolitik precepts with those of American Legal Realism, he insisted that when confronted with "the stubborn realities of international affairs" every nation on earth would act in its own self-interest "with all the power which discretion permitted." He continued:

International law in most important particulars never has been impartially just and never has been stable, but always has been and always will be a product of the interplay of national interests, prejudices and pressures, and therefore has been unstable, uncertain and controversial; since some of the doctrines of the learned are only the propaganda of powerful states more effectively advertised than the opposing propaganda of other states, any realistic, any intelligently hopeful efforts for improvement must start with recognition of these facts. ${ }^{67}$

With regard to the law of territorial waters in particular, Bingham declared that in this aspect "freedom of the seas" had come to mean a license for "destructive aggressions" against the fishery resources of the oceans beyond coastal jurisdictions. This trend toward destruction of marine fisheries could not prevail, he wrote, for "the irresistible tide of economic, political and social interests is running against the Anglo-American three-mile doctrine. It is doomed." ${ }^{\prime 8} \mathrm{He}$ praised the way in which the U.S. Supreme Court, faced with an unprecedented emergency in the Depression, and the manifest imperatives of possible "social calamity," had "displayed its statesmanship" by reversing long-honored doctrines that had proved inadequate to the nation's needs. Similar realism and flexibility were now required in international law of the oceans, Bingham declared; and doctrines no longer serviceable or defensible had to be scrapped ${ }^{69}$

Jessup responded with a defense of the traditional concepts, objecting to what he said was Bingham's tendency to portray himself as "progressive" and those whom he opposed as "necessarily doctrinaire." ${ }^{\text {" }} \mathrm{He}$ did not deny the validity of Bingham's view that international law had always been "dynamic" and capable of responding gradually to new realities; indeed, many rules had been modified in recent years, or, as with regard to rules for high seas transit of neutral flag ships in wartime, were obviously in need of modification. But he found misguided Bingham's analogy with the Supreme Court and its reversal of doctrine as applied to the New Deal's and the states' emergency measures. To be similarly legitimate, Jessup

66. Ibid., 56.

67. Ibid., at 56.

68. Ibid., at 61-62.

69. Ibid., at 58-59, 62-63.

70. Ibid., at 64 . 
asserted, reform of international law should be accomplished through treaties and multilateral efforts more generally, not through the kind of purely self-interested unilateral actions that Bingham advocated. ${ }^{71}$ Self-interest was invariably at play in international affairs, Jessup conceded; but in the long run, he insisted, it must be pursued in a manner which recognized that "a state's own interests are merely parts of the total interests of the society of nations."72

Bingham's legal views were cited widely on the eve of America's entry into World War II by salmon industry lawyers and lobbyists, who wanted Congress to enact legislation extending jurisdiction out to sea as far as necessary to exclude foreign competitors ("intruders," as they invariable termed Japanese and other potential new entrants to "their" fishing grounds). ${ }^{73}$ One especially influential advocate was the prominent international lawyer Edward W. Allen, a close friend of Bingham's, who in public speeches, scholarly journals, and trade publications stridently denounced the Japanese incursions and demanded action by the U.S. government. ${ }^{74}$ When Allen sent to Roscoe Pound at Harvard a reprint of one of his articles making the case-invoking Bingham's views for support-that would justify unilateral U.S. action to exclude foreign fishing from Bristol Bay, Pound was quick to respond; and he did not fail to take notice of the connection to Legal Realism in the debates of domestic law, especially Bingham's extreme view. ${ }^{75}$ Pound regarded as unprincipled and dangerous the emergence of such an explicitly pragmatic, consequentialist, position in the debate of ocean law. It is well worth quoting in full Pound's intriguing response to the Bingham-Allen view:

I can well believe that you are quite right as to the necessity of adjusting the three mile limit doctrine to the fisheries situation in the Northwest. Perhaps with my eye on recent extravagant statements of those who would abandon all historical continuity in connection with law and the administration of justice, I [bear] down too hard. But the world seems to me to be suffering

71. Ibid., at $62-66$.

72. Ibid., at 66.

73. In 1937 a bill had been introduced in the U.S. Senate to declare Bristol Bay within the continental shelf limits of the United States, hence territorial waters and not open to foreign fishing operations. A variant approach debated in Congress later was for a declaration that the United States had a proprietary interest in the salmon stocks; and, since they were thus declared to be "owned" by this country, they could not be fished by foreigners without U.S permission. See Jessup, “The Pacific Coast Fisheries," 136-38.

74. See, e.g., Edward Allen, "Control of Fisheries beyond Three Miles," Washington Law Review 14 (1939): 94. See note 52, above, for Allen's key role in commissioning Bingham to write his 1938 report on fisheries and offshore jurisdiction.

75. Cf. text at note 16 (regarding Pound's view of Bingham as perhaps extreme). 
from a notion that when it suits the convenience of some power to repudiate what had been settled in international relations it is at liberty to do so, and I earnestly hope that the [Northwest fisheries] matter ... can somehow be adjusted ... without giving aid and comfort to those who hold that whatever can get by is justified because it gets by. ${ }^{76}$

From Jessup and others in the traditional camp came the same type of criticism, only given even sharper focus by the parallel controversy that had raged among international lawyers over what they condemned as President Roosevelt's unprincipled policies in violation of -or at the very least, in a transparent evasion of-the Neutrality Acts by which Congress had sought to keep America clear of the hostilities gathering in Europe and Asia. ${ }^{77}$ To these critics, unilateral departures from the norms that had been articulated in international law were unacceptable because such actions were destabilizing and fraught with the danger that use of force would inevitably follow from such provocative policies. ${ }^{78}$

This is how the confrontation between traditionalists and Bingham stood, then, on the eve of America's entry into World War II. Bingham did not stand alone, however; for now, under heavy political pressure from the Pacific Coast, high-level U.S. diplomatic planners had begun to put together a strategy for a more aggressive policy on fisheries protection through a unilateral declaration of extended jurisdiction beyond three miles. This dramatic policy shift was also being impelled, however, by the related opportunity for the United States to assure its complete future control over seabed petroleum resources that lay more than three miles offshore, out to the limit of the Continental Shelf. ${ }^{79}$ As the war progressed, and the magnitude of American hegemony in world affairs became increasingly evident, the State Department and the Department of the Interior moved in a coordinated way to achieve both objectives. They were parallel objectives, in that each of them required serious modification, if not to say abandonment, of the long-established U.S. position that held the three-mile limit as a centerpiece of its approach to ocean law and ocean diplomacy. The story has been told elsewhere as to how these debates culminated in September 1945 with issuance by the White House of what became known

76. Letter from Roscoe Pound to Edward W. Allen (September 19, 1939, Edward W. Allen Papers, University of Washington Library).

77. For a review of the controversy in political and academic discourse over the Neutrality Acts, see Aaron X. Fellmeth, "A Divorce Waiting to Happen: Franklin Roosevelt and the Laws of Neutrality, 1935-1941," Buffalo Journal of International Law 3 (1996-97): 413-517.

78. Jessup and other speakers, on the panel reported in ASIL Proceedings, $54 \mathrm{ff}$.

79. Ann L. Hollick, U.S. Foreign Policy and the Law of the Sea (Princeton: Princeton University Press, 1981), 18-61. 
as the two "Truman Proclamations." 80 The better-known of the two proclamations declared U.S. ownership of the seabed and its resources, most notably including petroleum deposits, out to the limits of the Continental Shelf.

The other proclamation, known as the "Truman Fisheries Proclamation," appeared to adopt in a robust version the Realist premises and policy on coastal fishery waters that Bingham had advocated in his 1939 Report. President Truman declared that the United States was prepared to establish and control "conservation zones" as far out to sea as necessary beyond three miles, in order to regulate fishing by both American and foreign vesselsand thereby to assure the sustainability of salmon and other valuable coastal fishery stocks. A supplementary letter issued the same day made explicit that the new policy was intended to protect the American-flag salmon fishing fleet in Bristol Bay and other coastal areas of the Northeast Pacific. ${ }^{81}$

This breakthrough in American policy was a moment of high triumph for Bingham and his allies in the fishing industry, in the diplomatic policy planning community, in the academy, and among working international lawyers. It was a short-lived triumph, however; for as it turned out, the U.S. government never implemented the fisheries proclamation. The main effect of Truman's fisheries proclamation was ironic and in the end selfdefeating. Together with the continental shelf declaration, it served in fact to inspire similar declarations by Latin American governments, announcing extended offshore jurisdiction to protect their coastal fishing industries; and in some instances, these states claimed actual ownership and full sovereignty over ocean areas far out to sea ${ }^{82}$ Unlike the United States, which backed off from the policy that had been announced, the Latin American nations moved toward immediate implementation. This was damaging, both immediately and potentially over time, to the distant-water American tuna fishing interests; and the tuna industry leadership in Southern California on the West Coast, a powerful group politically, pushed hard to head off any implementation of the Proclamation. Giving potent support to the tuna interests in their opposition was the U.S. Navy leadership. The

80. Ibid.; and D. C. Watt, "First Steps in the Enclosure of the Oceans," Marine Policy 3 (1979): 219-20 et passim.

81. Proclamation No. 2668 (Sept. 28, 1945), Federal Register 10 (1945): 12304, on which see Hollick, U.S. Foreign Policy, 47-61; and Scheiber, "Origins of the Abstention Doctrine," 34-35.

82. David Joseph Attard, The Exclusive Economic Zone in International Law (New York: Oxford University Press, 1987), 1-20; cf. F. V. Garcia-Amador, "The Latin American Contribution to the Development of the Law of the Sea," American Journal of International Law 78 (1974): 33. For a perceptive contemporary analysis, see Richard Young, "Recent Developments with Respect to the Continental Shelf,' American Journal of International Law 42 (1948): 849. See also note 84, below. 
Navy's concern was that if extended jurisdiction were to be declared by coastal nations globally, and jurisdiction well beyond three miles became accepted as customary international law, then the U.S. submarines and surface ships could be denied passage in strategically critical areas, and Navy intelligence-gathering vessels would be kept far off the shores of hostile powers. In addition, an abiding opposition to implementation of the Proclamation came from many State Department officers, who were concerned that it represented a protectionism, achieved through unilateral action, that undermined the larger U.S. postwar policy of fostering free access to natural resources and the building of institutions and precedents for multilateralism in global affairs. ${ }^{83}$

Many international lawyers shared these concerns. Indeed, even some of the legal scholars who were sympathetic to Bingham's position responded to his writings on these issues from 1949 through the mid-1950s as being too extreme. His critics charged that Bingham was recklessly unmindful of the complexity of U.S. fishing interests in that he seemed to have no sympathy for the need of American tuna boats to fish in other nation's near-offshore waters. Some eminent colleagues in international law studies also believed that he was insensitive to the danger that the trend to offshore claims of special jurisdiction over fishing were already giving way to the outright claims to full sovereignty by some Latin American states with respect to ocean areas twelve miles or even farther offshore. ${ }^{84}$

83. Within the State Department, there were many top officers who were dogmatic on the three-mile rule, as reported by the insider Wilbert Chapman, who served for three years as chief fisheries officer in the department. But Chapman later told the salmon industry lawyer and champion Edward Allen that the most effective source of pressure in this regard had come from the Department of Defense and the National Security Council, motivated by a concern to maintain U.S. naval strategy, as stated in the text above. Letter from Chapman to Edward Allen, April 3, 1956, American Tunaboat Association Papers, Scripps Institution of Oceanography Archives, University of California, San Diego.

84. Ecuador, whose actions were particularly hostile to U.S. tuna-fishing interests, stopped and held U.S. flagged fishing boats as far as twenty-five miles offshore in 1953-54, and Peru seized and detained five Onassis fleet Greek-flag whaling vessels 160 to 364 miles offshore in November 1954, holding them from release until stiff fines were paid. Hollick, U.S. Foreign Policy, 87. It is important to mention, however, that in his ocean law writings from 1938 to the 1950s, Bingham often contended for the need to respect the interests of less developed coastal countries; they were short of resources and lacking in naval power, and for economic reasons they needed to extend their fisheries jurisdictional claims to considerable distances offshore. In 1939 he had urged the United States, as a powerful state whose example would win emulation, to lead the way in extending jurisdiction, as America had "a clearly just claim" in the Bering Sea case and could mobilize "skillful diplomatic support" of a new rule. Bingham, Report, 41 . He wrote in 1952: "We live in a revolutionary age when the peace and welfare of the world urgently demand in international affairs cooperation and just recognition of the interests of small states as well as large . ..." Joseph Walter Bingham, "Juridical Status of the Continental Shelf," Southern California Law Review 26 (1952): 8. 
Bingham also voiced criticisms of American policies more generally that alienated even formerly sympathetic international lawyers. This divergence of views came to a head for the ocean law experts in 1956, when he drafted a report for an Inter-American Bar Association meeting in which he likened the "awakened claims of national jurisdiction" by Latin American states (claims to full sovereignty over ocean zones 200 miles offshore) to the "bitter complaints of nationally awakened Asiatic peoples" and Pacific islanders with regard to U.S. nuclear tests in the Pacific. His fellow committee members representing the American bar, all of whom he had expected to join in this report-even his old ally, the Seattle lawyer Edward Allen-declined to sign his report. ${ }^{85}$

One prominent critic, rather surprisingly, was William Bishop, who had

Bingham later blended his concern for emerging nations with a bitter critique of U.S. policies in the Cold War-a phase of his career that can be mentioned only parenthetically here: He stated in his later memoir that, since the end of World War II, he had been largely ostracized by the American community of academic international lawyers for the beliefs he freely voiced concerning U.S. policies. In foreign affairs, Bingham wrote, the citizens were "illy [sic] informed and led, and have been incited to intolerance and hatred of necessary social, economic and political developments throughout the world ... The deaths and sufferings of millions of people all over the world is another consequence of our policies." He persisted in these criticisms during the period when the anti-Communist agitation, epitomized by Senator Joe McCarthy, was silencing so many critics. Bingham, List of Writings, Postscript, 5-6. Instead of pursuing humane and altruistic policies "[to] further the needs and possibilities of the masses of humanity," America had pursued an aggressive and arrogant course-_"the most shocking development," he wrote, "in all my knowledge of history." Ibid., at 86 . So far as I can learn, Bingham conveyed these ideas in meetings and conversations for the most part, not in formal writings. In any event, Bingham recalled, he had been denied salary raises and recognition by his own faculty at Stanford. The isolation he felt at home was in contrast to the continuing interest, as he recounted, in having him participate in academic and policy discourses with his British and other European colleagues. Ibid., at 66, and Postscript, 1-7. Even in 1936, Bingham was concerned about his advocacy of reform being misinterpreted and alienating, stating in a lead footnote that his critiques of the law should not be taken as advocacy of socialist or communist alternatives. "It is significant of the turmoil of passion and prejudice in our current debates on matters of politics and government," he wrote, "that a credo caveat of this sort is necessary even in a studious discussion of a legal problem." Bingham, "The American Law Institute vs. the Supreme Court," 393n.

85. Bingham, List of Writings, 107-8; and reports and quotations of Bingham's draft in letters of William W. Bishop, Jr., to Bingham, February 26, 1956, and March 16, 1956 (in the Chapman Papers, University of Washington Library). Bingham wrote later that he had been able to exert some influence with the Department of State during the Truman administration years, but that in the Eisenhower Administration there was renewed dedication to the three-mile doctrine, and thereafter he received a more respectful hearing for his views in foreign countries than in his own. Bingham, List of Writings, 63-66. Actually the State Department's reversal on the three-mile doctrine began earlier. See text at notes 87-88, below. 
led the legal staff in crafting the Truman Proclamation policy when he was a State Department officer during the war. In the postwar years, Bishop parted ways with Bingham on the three-mile issue when they served together on the delegation representing the American bar at the 1956 meeting. Refusing to sign Bingham's draft report, Bishop said that it "adopt[ed] the Latin-American line almost 100 per cent," and that in effect could be taken as a brief for Latin American states that were seizing U.S. fishing vessels outside of the three-mile boundary. It did not discriminate, Bishop complained, between the legitimate protection of "historic" coastal fishing interests and simple aggrandizement through the offshore version of a land grab. $^{86}$

Bingham carried on his campaign in many forums nonetheless; but it proved to be a losing fight, at least in the short term. For in the face of the aforementioned pressures, the State Department's chief fisheries officer, Wilbert McLeod Chapman, issued a formal statement in December 1948-a little more than three years after issuance of the Truman Proclamationtreating the Proclamation as essentially inoperative and affirming America's renewed adherence to the three-mile rule.$^{87}$ For the British Foreign Office planners, as for others dedicated to the three-mile rule in the face of new challenges-such as the challenges from Iceland and Norway, nations that were then seeking to ban British trawlers from their coastal waters well beyond the traditional line-Chapman's statement of policy was greeted as a gratifying announcement that the United States was abandoning its short-lived championing of "the Bingham doctrine." 88

This reversal of U.S. policy came too late, however, to save the traditional rule in international affairs; for once the "extended jurisdiction" genie had

86. Letter from Bishop to Chapman, March 21, 1956, Chapman Papers, University of Washington Library; also, letter from Bishop to Bingham, Feb. 26, 1956, ibid.

87. Wilbert M. Chapman, “U.S. Policy on High Seas Fisheries," Department of State Bulletin 20 (1949): 67-7. This policy paper declared that it would be U.S. policy to foster the development of scientific international fisheries management through bi- and multi-lateral agreements. Privately, Chapman told leaders of the fisheries industry on the West Coast that the Truman Proclamation was politically unworkable precisely because of its "broad sweeping implications-its new philosophy and its radical departure from holy precedent" on the matter of the three-mile limit. Letter from Chapman to Montgomery Phister, Nov. 24, 1947, Chapman Papers. For analysis of Chapman's role in its political context, see Harry N. Scheiber, "Pacific Ocean Resources, Science and Law of the Sea: Wilbert M. Chapman and the Pacific Fisheries," Ecology Law Quarterly 13 (1986): 383, 455-61.

88. The phrase was used explicitly, for example, by British Foreign Office officials in meetings with U.S. diplomatic planners, 1950-51. See note 4 above and accompanying text. On one of the earliest of the dangerous post-1945 ocean conflicts over fishing in territorial waters, see Hannes Jónsson, Friends in Conflict: The Anglo-Icelandic Cod Wars and the Law of the Sea (London: C. Hurst, 1982). 
been let out of the bottle, getting it back in proved impossible. ${ }^{89}$ In both national politics and international relations, there was rising pressure for extended fishery jurisdiction. This pressure came from nations whose fishing industries were almost exclusively coastal, but also from the coastal-fishing sectors of larger countries (including the salmon industry of the United States itself) that had both coastal and distant-water fleets. Also concerned to extend their claims to marine fisheries far out beyond three miles offshore were many Third World coastal nations and small island states, then emerging as assertive and vocal players in global diplomacy during the postwar wave of decolonization. These proponents of extended jurisdiction, successfully forming effective coalitions as the issue moved into the United Nations, gradually gained the upper hand in the reconfigured international debate of ocean law. ${ }^{90}$

Still, Bingham's voice continued to be heard in the resultant international discourse as to how the territorial-waters issues should be resolved. In the public realm, he served as a consultant to an international fisheries commission for the North Pacific; ${ }^{91}$ and he gave testimony before Congress with regard to regulation of fisheries and control of petroleum resources in offshore ocean areas. ${ }^{92}$ In the lively academic exchange that raged on the law of territorial waters and fisheries from 1945 to the 1980s, his best known contribution was an article published in 1952 entitled "Juridical Status of the Continental Shelf." 93 Bingham incorporated in this study several long and key passages nearly verbatim from his 1940 ASIL panel presentation, but now the context was entirely different: In 1940, his objective had been to champion a reversal of U.S. policy and a new view of international law; in 1952, however, his goal was to save a victory that

89. For reference to the Truman Proclamation and its unintended consequences as a case of the genie let out of the bottle, see Robert L. Friedheim, Negotiating the New Ocean Regime (Columbia: University of South Carolina Press, 1992), at 21.

90. See Douglas M. Johnston, The International Law of Fisheries: A Framework for Policy-Oriented Inquiries (New Haven: Yale University Press, 1965), 232-33, 332-44 and Hollick, U.S. Foreign Policy, passim. Insofar as the United States resisted as long as it did, no doubt the principal influence on its policy was the U.S. Navy's interest, as noted above (note 83).

91. Hancock, "Memorial Resolution." (The commission in question was the International North Pacific Fisheries Commission, established in 1953 in implementation of a CanadianU.S.-Japanese fisheries convention for the Northeast Pacific.)

92. Testimony [on effects of the Truman Proclamation and on the continental shelf doctrine] in Hearings on S. 1901 Before Senate committee on Interior and Insular Affairs, 83d Cong., 1st Sess. 438-43 (1953).

93. Bingham, "Juridical Status of the Continental Shelf," 4-20; see also his earlier article, Joseph Walter Bingham, "The Continental Shelf and the Marginal Belt," American Joumal of International Law 40 (1946): 173. 
seemed to be slipping away-that is, to contend for the immediate and vigorous implementation of the Truman Fisheries Proclamation. Bingham still championed the Proclamation as representing a salutary "revolutionary step" toward establishment of new, realistic principles in ocean law. ${ }^{94}$ The basic problem remained as it had been since the 1930s, Bingham averred: It was the need to defend coastal fisheries against "piratical [ sic] invasions of coastal fisheries by large foreign organizations, resentful of any control over their destructive methods and careless of the damage they cause to important sea food resources of coastal peoples." ${ }^{95}$ Assessing the long list of nations that had declared jurisdiction or even outright sovereignty over coastal waters out beyond three miles since 1945, Bingham conceded that some of their claims were "excessive and infringe[d] too far with insufficient reasons on the traditional doctrine of freedom of the seas . . . "96 For this seasoned pragmatist, however, it was the phrase "insufficient reasons" that held the key to the policy question: Extended jurisdiction would be justified only to protect "true coastal fisheries ... and those fish which traditionally have been caught in commercial quantities only in shallow off-shore waters" (a concise description of the American salmon industry off Alaska's coast). Jurisdiction beyond traditional limits offshore would not be justified, however, "to cover on the high seas species of fish which are caught principally in deep sea waters" (an equally concise description of the tuna fisheries, in which a dominant force internationally was the San Diego tuna fleet-a fleet whose leadership had successfully opposed since 1945 any active implementation of the Truman Proclamation). ${ }^{97}$

94. Bingham, "Juridical Status of the Continental Shelf," 6.

95. Ibid., at 8 .

96. Ibid., at 9. The trend toward extended claims accelerated in the 1970s, as the UN meetings that led to the new Convention were going forward. As of 1986, four years after signature of the Convention, of 136 coastal states, there were 114 claiming full territorial jurisdiction offshore from 3 to 12 nautical miles ( 89 of them at 12 miles). Ten states had extended their territorial sea claims to more than 12 miles, fifteen claiming territorial sovereignty up to 100 miles. V. F. Tsarev, "Maritime Legislation of Coastal State and the 1982 UN Convention on the Law of the Sea," in The Law of the Sea: What Lies Ahead? 531n. Law of the Sea Institute, 20th Annual Conference, Proceedings, ed. Thomas A. Clingan, Jr., n.d. See generally William T. Burke, The New International Law of Fisheries: UNCLOS 1982 and Beyond (Oxford: Clarendon Press, 1994), for authoritative analysis, with historical background of modern ocean law.

97. Italics added. It was ironic that the Japanese distant water tuna-fishing interestswhich were now focused heavily on fishing tuna in high seas waters off other nations' coasts, as the Japanese salmon fleet had been when threatening Bristol Bay in 1937-38-was in the period from the mid-1950s to the 1990s an important ally of the U.S. tuna-fishing fleet interests in contending internationally for non-jurisdiction by any coastal state over "highly migratory species," a category that consisted almost exclusively in commercial terms of tuna. See Harry N. Scheiber, "U.S. Policy, the Pacific Tuna Economy, and Ocean Law Innovation: The Post-World War II Era, 1945-1970," in Bringing New Law to Ocean Waters, eds. David D. Caron and Harry N. Scheiber (Leiden: Martinus Nijhoff, 2004), 29-54. 
As one would expect, given Bingham's previous major writings, his argument turned in the end upon a pragmatic standard: "New problems need new thinking . ..." Barriers to rational change posed by adherence to "traditional juristic formulations," he contended, "must not be allowed to prevail. ${ }^{98}$ The contemporary generation should not be held prisoner by the legacy of an irrelevant past. What he termed "democratic law," i.e., law that would be responsive to needs in the real world, must develop by acceptance of "competitive forces and varying conditions" in contemporary life. The alternative to such a rational course would be the same kind of socially harmful applications of law as he had attacked nearly half a century earlier in his condemnation of classical legal formalism. Bingham despised what he scornfully termed

mechanistic adherence to traditional ill-digested generalities and slogans devised by theoreticians of an unscientific age of subsidized piracy, matchlocks, wood fires, and candlelight, wide-open spaces, and glorification of cruel aggressive force for self-profit-theoreticians who could have foreseen little of the technology, industries, social pressures, and dominant impulses of our crowded, complex, modern civilization. ${ }^{99}$

Bingham died in 1973, so that he could not savor the conclusion of the protracted negotiations that led to signature in 1982 of the United Nations Convention on the Law of the Sea (UNCLOS), codifying reforms he had advocated for thirty-five years. He did, however, witness late in his lifetime the unilateral extension of U.S. jurisdiction over fishing, by act of Congress in 1966, to a distance of twelve miles offshore. ${ }^{100}$ Then in 1975, Congress legislated -in a bill signed reluctantly by President Gerald Ford, who would have preferred to stay America's hand until UN negotiations on the general treaty had been concluded-for unilateral creation of a 200-mile zone offshore that included full U.S. regulatory control over fishing by any nation. ${ }^{101}$

By validating the concept of extended fishery jurisdiction in an "Exclusive Economic Zone" (EEZ) out to 200 miles offshore of any coastal nation that wished to declare such a zone, the 1982 UNCLOS agreement essentially made universal the extended jurisdiction policy. This agreement represented a long-delayed triumph in international law of Bingham's po-

98. Bingham, "Juridical Status of the Continental Shelf," 19.

99. Ibid. at 20.

100. Harry N. Scheiber and Christopher Carr, "Constitutionalism and the Territorial Sea: An Historical Study," Territorial Sea Journal 2 (1992): 67 . The 1966 act referred to in the text is Public Law 89-658, 80 U.S. Stat. 908 (Oct. 14, 1966).

101. Scheiber and Carr, "Constitutionalism," 68-70. The bill in question became known as the Magnuson Fishery Conservation and Management Act, and in later amended form as the Magnuson-Stevens Act. 16 U.S.C. $1801=1882$, April 13, 1976 as amended 1978-80, 1982-84, 1986-90, 1992-94, 1996 and 2006. 
sitions on the question of fisheries protection through extended offshore jurisdiction. The UNCLOS also declared it to be an obligation of signatory nations to manage their fisheries in a sustainable manner within their EEZs and to support the objective of sustainability with regard to high seas fisheries beyond the 200-mile lines. Here, too, the arguments that Bingham, along with Riesenfeld, had made forty-three years earlier resonated in the obligations placed on coastal and distant-water fishing states in the UNCLOS agreement. For these pioneers in carrying Legal Realism offshore had insisted from the start that unilateral action, such as they wanted the U.S. government to take, should be only the indispensable beginning for a process in organic international lawmaking that could bring the community of nations to agree on new principles of sustainability and conservation of ocean resources. ${ }^{102}$

And so this new-and in our day forgotten-variant of Legal Realism, in the tradition of the American movement of the 1920s and 1930s, and infused with the DNA of Old World Realpolitik, had gone offshore successfully. By foreshadowing the general thrust and even charting the basic outlines of reform in a vital realm of international law. Joseph Walter Bingham had been at the storm center in this process, and his role in this transformation of international law was a large one. It is well to recall, however, that Bingham's basic posture on international ocean law concerning both what degree of respect was owed to tradition in the law, and what objective imperatives required reforms, was derived from his position on jurisprudence at the very start of his career, when he had advocated so ardently the philosophy that later reached full flower with the Legal Realist school.

102. See Scheiber and Carr, "From Extended Jurisdiction to Privatization," 13-16. 